\title{
Baku Mutu Lingkungan Sebagai Instrumen Pengendalian Lingkungan Hidup Kasus Galian C di Kabupaten Karangasem
}

\author{
I Gusti Ayu Widiadnyani', Putu Tuni Cakabawa Landra² \\ ${ }^{1}$ Kantor Notaris Ni Made Dwimayeni Sawitri, E-mail: 19widiadnyani@gmail.com \\ 2Fakultas Hukum Universitas Udayana, E-mail: tuni_cakabawa@unud.ac.id / \\ putusakabawa@yahoo.com
}

\begin{tabular}{l} 
Info Artikel \\
\hline Masuk: 17 Maret 2020 \\
Diterima: 8 Agustus 2020 \\
Terbit: 30 September 2020 \\
\\
Keywords: \\
Evironmental Quality \\
Standards; Mining excavation \\
C; Living Environment.
\end{tabular}

Kata kunci:

Baku Mutu Lingkungan;

Pertambangan galian C; Lingkungan Hidup.

\begin{abstract}
Mining activities can include exploration, exploitation, production, refining, and selling. Mining can be converted into business land in accordance with the industrial revolution, which is 4.0 (four point zero). Bali Island has the potential of $C$ excavated material located in Karangasem Regency. Existing mining due to the eruption of Mount Agung is used by the community to produce tradable materials. The purpose of this study is to examine environmental quality standards as instruments for environmental control of the $C$ excavation case in Karangasem Regency. This research uses normative legal research methods. The approach used is the statutory and conceptual approach. The legal materials used are primary, secondary, and tertiary sources of law. Legal material analysis techniques use description and argumentation. The results of the study indicate environmental quality standards as a boundary measure of environmental pollutant elements. The case of excavation $C$ in Karangasem Regency, the provincial government and the regional government worked together to issue a Mining Business Permit Regulation as a legal regulation that must be obeyed by business people and the community in the excavation environment $C$. That it has been prohibited from excavating nonmetal minerals and rocks in the area with an altitude higher than 500 meters above sea level and curbing the stone mining permit area within the province and sea area for up to 12 miles. Implementation of environmental preservation includes: first, prevention; second, prevention; and third, recovery as a preventive measure for environmental pollution due to mining activities in $C$.
\end{abstract}

\begin{tabular}{l} 
Abstrak \\
\hline Kegiatan pertambangan dapat meliputi eksplorasi, eksploitasi, \\
produksi, pemurnian, serta penjualan. Seperti yang saat ini \\
diterapkan bahwa pertambangan bisa dijadikan lahan bisnis \\
sesuai revolusi industri yaitu 4.0 (four point zero). Sehingga \\
dengan perkembangan revolusi industri saat ini terdapat \\
berbagai sektor perekonomian salah satunya sektor \\
pertambangan. Pulau Bali memiliki potensi bahan galian Cyang \\
terletak di Kabupaten Karangasem. Pertambangan yang ada \\
akibat letusan Gunung Agung dimanfaatkan oleh masyarakat
\end{tabular}




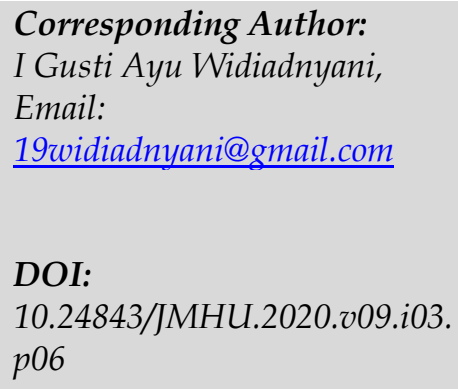

\section{Pendahuluan}

Seiring berkembangnya zaman kehidupan manusia saat ini memiliki kebutuhan yang beranekaragam. Salah satunya yang bisa dilihat yaitu adanya sumber dari kekayaan alam yang dimiliki merupakan suatu unsur dalam tatanan lingkungan hidup yang telah menjadi suatu kebutuhan setiap aktivitas yang dilakukan dalam kehidupan manusia. Cadangan sumber daya alam saat ini seperti yang diketahui sudah semakin menipis. Disaat yang sama permasalahan juga dihadapi oleh lingkungan seperti semakin menurunnya kualitas lingkungan maupun perlu mendapatkan perhatian lebih. Kerusakan tatanan alam dan lingkungan yang telah terjadi berkaitan erat dengan penduduk. Keterkaitan antara penduduk, baik alam dan lingkungan disebabkan oleh faktor sosial dan cara pandang penduduk yang kurang menyadari akan pelestarian kekayaan alam dan lingkungan yang merupakan faktor kunci dalam kelangsungan hidup mereka. ${ }^{1}$ Salah satunya dibidang pertambangan yang saat ini digeluti oleh masyarakat. $^{2}$

Ditengah kehidupan bermasyarakat, berbangsa dan bernegara terdapat sebuah konsep yang disebut Tri Hita Karana. Aktivitas pertambangan yang dilakukan secara berkelanjutan harus diimbangi dengan adanya Tri Hita Karana diantaranya: pertama,

1 Maryunani. (2018). Pengelolaan Sumber Daya Alam dan Pembangunan Ekonomi Secara Berkelanjutan. Malang: UB Press, p. 8-9.

2 Firmansyah, A. A., \& Evendia, M. (2014). Politik Hukum Penetapan Baku Mutu Lingkungan sebagai Instrumen Pencegahan Pencemaran Lingkungan Hidup. Kanun: Jurnal Ilmu Hukum, 16(1), p. 19. 
parahyangan merupakan hubungan yang terjadi antara manusia dengan tuhan, kedua, adanya palemahan adalah hubungan yang terjadi antara manusia dengan alam lingkungan, dan yang terakhir pawongan yaitu hubungan yang terjadi antara manusia dengan sesamanya). Tri Hita Karana yang dikenal menjadi sebuah filosofi penyebab terjadinya suatu keseimbangan hidup masyarakat Hindu yang berada di Bali. ${ }^{3}$ Dalam kehidupan ini hubungan antara manusia dan lingkungan sangat erat kaitannya, dikarenakan kegiatan yang dilakukan oleh manusia sangat dipengaruhi oleh tatanan lingkungan. Apabila pemanfaatannya tidak dilakukan secara bijaksana dapat menimbulkan kerusakan lingkungan. Fenomena tersebut merupakan bagian yang tidak terpisahkan oleh kehidupan manusia, sehingga sebagai pelaku usaha untuk tetap menjaga hubungan manusia dengan alamnya dan menjalankan usahanya agar lebih bertanggungjawab. Secara tidak langsung dari potensi yang ada sumber daya alam memiliki manfaat untuk seluruh masyarakat terutama dalam bidang ekonomi dan dapat dijadikan peluang untuk menghasilkan pendapatan. ${ }^{4}$

Salah satu yang menjadi sumber daya bagi kehidupan manusia dalam bidang perekonomian adalah pertambangan. Adapun sarana prasarana serta adanya sebuah peralatan yang masih sangat sederhana hingga canggih yang berasal dari bahan baku suatu komoditas tambang, dengan adanya bahan mineral logam kemudian mineral non logam, dan terakhir adanya batuan. Sehingga baik dari batubara serta radioaktif dikatakan sebagai sumber energi yang bermanfaat. Untuk saat ini perkembangan pertambangan memiliki berbagai potensi yaitu komoditas seperti pasir, koral yang digali oleh masyarakat. Hal ini menyebabkan peranan dalam komoditas ini digunakan oleh masyarakat sebagai bahan bangunan. Begitu pesatnya kegiatan proses pembangunan di berbagai bidang yang terjadi sehingga meningkatnya ketersediaan suatu bahan yang dibutuhkan. Kerusakan lingkungan yang sering terjadi disebabkan oleh kegiatan pertambangan yang dilakukan secara berkelanjutan. Sehingga perekonomian masyarakat berpengaruh besar terhadap kegiatan pertambangan. Perubahan yang saat ini sering terjadi dilihat dari manusia bisa bernafas karena adanya udara, kemudian adanya terang cahaya karena matahari sehingga kebutuhan manusia dengan mendapat makan maupun minum itu semua dari lingkungan. ${ }^{5}$

Adapun sumber daya alam yang sangat bermanfaat diantaranya batu-batuan, besi maupun emas hal itu dilakukan dengan penggalian dan dijadikan sebagai bahan galian sebuah industri oleh masyarakat. Kabupaten Karangasem melakukan kegiatan penambangan bahan galian yang merupakan penambangan rakyat serta dalam aktivitas pertambangan yang dilakukan oleh warga menggunakan alat-alat yang masih sederhana diantaranya sekop maupun linggis. Aktivitas kegiatan yang dilakukan dalam penambangan galian $C$ tersebut menimbulkan berbagai dampak yaitu adanya dampak positif maupun timbulnya dampak negatif. Adanya dampak positif yang ditemui adalah masyarakat memiliki pekerjaannya untuk memenuhi

\footnotetext{
${ }^{3}$ Pertiwi, I. D. A. E., \& Ludigdo, U. (2013). Implementasi Corporate Social Responsibility Berlandaskan Budaya Tri Hita Karana. Jurnal Akuntansi Multiparadigma, 4(3), DOI: http://dx.doi.org/10.18202/jamal.2013.12.7208, p. 432.

${ }^{4}$ Jumali, J., Farhan, N., Razma, O., Amalia, N. F., \& Sudarmiati, S. (2017). Peran Pemerintah Daerah Dalam Mengoptimalisasi Penanganan Pencemaran Lingkungan di Wilayah Pesisir Kota Batam. Jurnal Selat, 5(1), p. 27.

${ }^{5}$ Siahaan, N. H. T. (2009). Hukum Lingkungan, cet. Ke-2, Jakarta: Pancuran Alam, p. 1-2.
} 
perekonomian keluarganya, jalan penduduk yang mulanya belum layak kini sudah bisa memperlancar lajur dalam transportasi. Tidak hanya dampak positifnya saja yang ditimbulkan tetapi muncul dampak negatifnya yaitu aktivitas pertambangan yang dilakukan secara berkelanjutan menimbulkan lubang-lubang yang besar sehingga lahan yang ada menjadi tidak produktif akibat penambangan yang dilakukan secara terus-menerus dan pada saat musim hujan tiba muculnya sarang nyamuk akibat lubang tersebut sehingga dapat menimbulkan penyakit kepada masyarakat sekitar. ${ }^{6}$

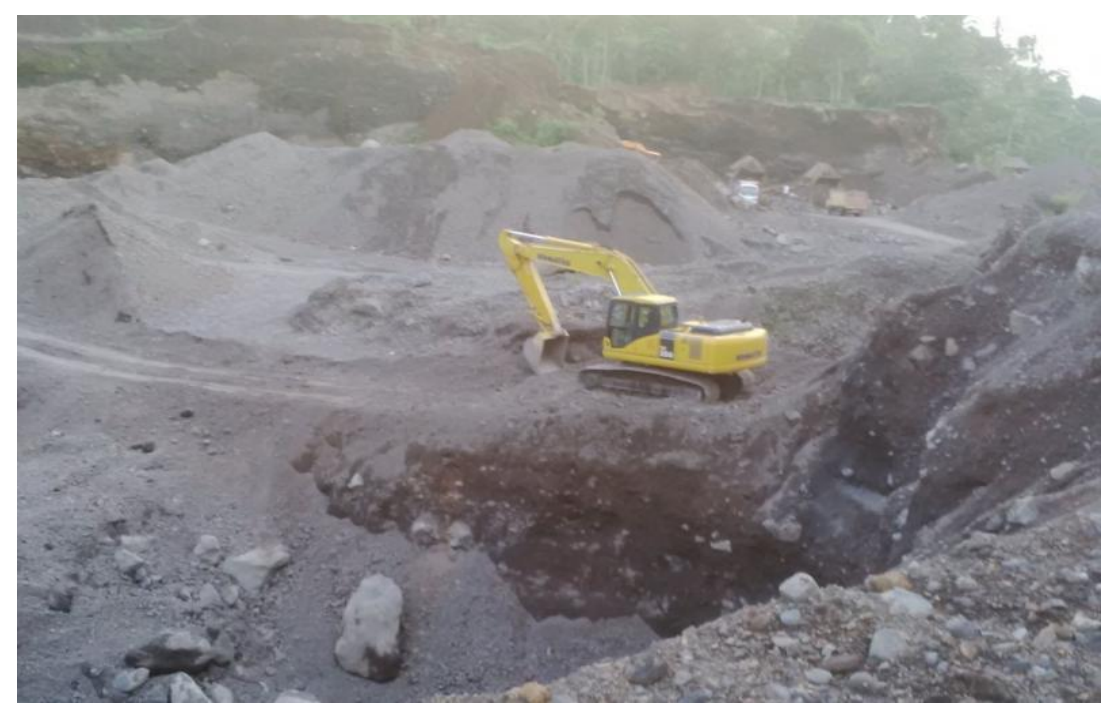

Gambar 1. Penambangan Galian C di Kabupaten Karangasem Sumber. https://www.balipost.com/news

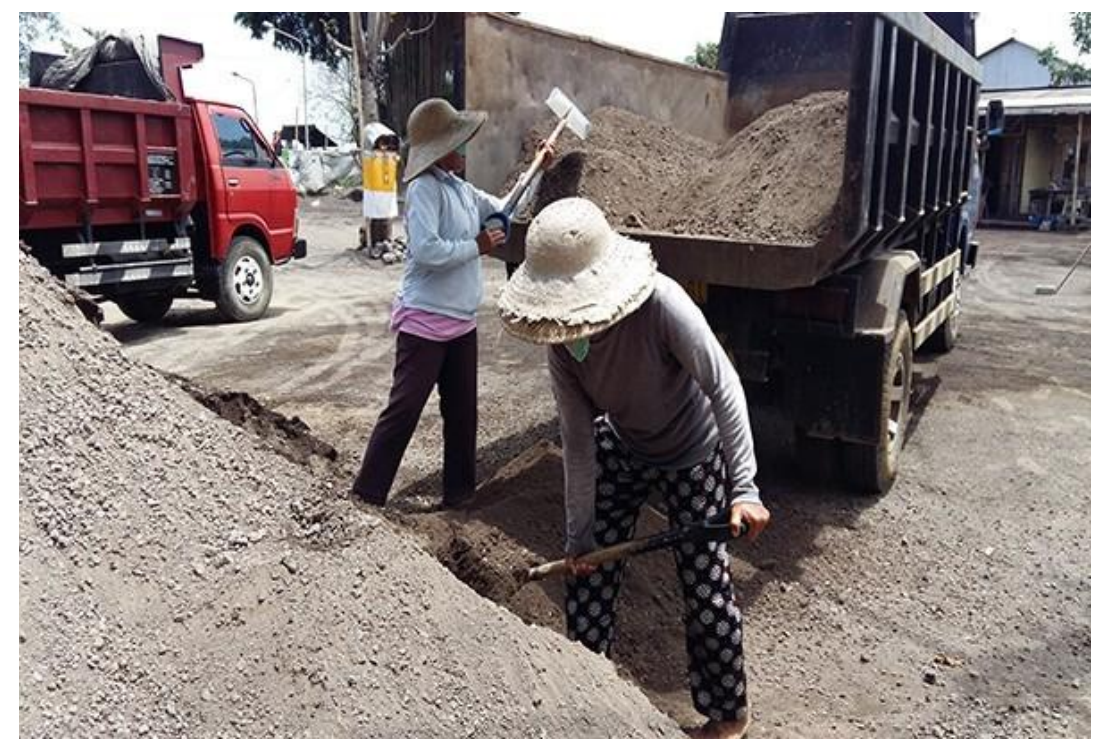

Gambar 2. Aktivitas Pelaku Usaha Galian C di Kabupaten Karangasem Sumber. https://www.balipost.com/news

Seperti yang terlihat dalam Gambar 1 dan Gambar 2, terdapat aktivitas penambangan galian $C$ di Kabupaten Karangasem. Potensi pertambangan dari galian $C$ tersebut

\footnotetext{
${ }^{6}$ Rissamasu, F., Darma, R., \& Tuwo, A. (2011). Pengelolaan Penambangan bahan Galian Golongan C di Kabupaten Merauke. Ejournal Pascasarjana Universitas Hasanuddin, 56-57.
} 
menjadi primadona bagi para investor. Selain itu aktivitas pertambangan juga dapat menopang kebutuhan hidup masyarakat. Namun dibalik proyek-proyek tersebut terdapat pelaku usaha yang tidak memperhatikan berbagai pencemaran yang akan ditimbulkan dari aktivitas pertambangan tersebut dan pelaku usaha tidak menerapkan baku mutu lingkungan dalam melindungi dan mengelola pelestarian lingkungan. Selain itu pengelolaan dan pemanfaatannya dapat digolongkan menjadi bahan galian industri yang menjadi 3 (tiga) golongan yaitu: galian strategis termasuk ke dalam golongan bahan galian A yang terdiri dari batu bara, nikel, timah dan aspal kemudian galian vital golongan masuk ke dalam bahan galian B yang terdiri dari besi, belerang, dan emas selanjutnya galian bukan vital dan bukan strategis terdiri dari marmer, batu kapur dan granit. ${ }^{7}$ Kegiatan pertambangan dapat meliputi eksplorasi, eksploitasi, produksi, pemurnian, serta penjualan. Seperti yang saat ini diterapkan bahwa pertambangan bisa dijadikan lahan bisnis sesuai revolusi industri yaitu 4.0 (four point zero). Sehingga dengan perkembangan revolusi industri saat ini pertambangan merupakan komuditas yang sangat berpengaruh di dalam kegiatan pembangunan perekonomian pada umumnya di Indonesia dan secara khusus yang ada di daerah. ${ }^{8}$

Berbagai sumber kekayaan alam di Indonesia yang beranekaragam dilihat dari sumber daya alamnya. Mengenal berbagai kekayaan alam yang dimiliki oleh Indonesia yang dilihat dari adanya sumber kekayaan alam yang dapat diperbaharui dan kekayaan alam yang tidak dapat diperbaharui. ${ }^{9}$ Pulau Bali yang letaknya di Negara Indonesia menyimpan pesona alam bahkan tidak perlu diragukan lagi Pulau Bali sebagai salah satu destinasi yang selalu dikunjungi oleh wisatawan lokal maupun mancanegara karena kearifan lokal dan budaya maupun tradisi yang masih kental dijaga oleh masyarakat Bali dan memegang teguh adat istiadat secara turun-temurun. Dibalik keindahan Pulau Bali terdapat potensi alam yang tidak perlu diragukan lagi dilihat dari potensi pertambangan yang ada yaitu potensi bahan galian C. Letaknya di Kabupaten Karangasem. Potensi pertambangan yang ada akibat letusan Gunung Agung dimanfaatkan oleh masyarakat sebagai peluang perekonomian untuk menopang kebutuhan hidup. Pengelolaannya pun dilakukan dengan penggalian sehingga menghasilkan bahan material yang dapat diperjualbelikan untuk berbagai kebutuhan dalam pembangunan.

Wilayah daerah penambangan galian $\mathrm{C}$ di Kabupaten Karangasem merupakan daerah dengan potensi yang banyak mempunyai kandungan-kandungan bahan tambang seperti pasir, koral, batu serta lainnya yang pada umumnya digunakan bahan material bangunan. Proses penambangan galian ini dilakukan secara kontinu di titik-titik yang kandungan pasir serta batu-batunya banyak. Aspek keuntungan yang selalu diutamakan namun mengabaikan lingkungan sekitar masih dilakukan oleh pengusaha galian Golongan C Sehingga hal tersebut, mengakibatkan keseimbangan antara

\footnotetext{
7 Valia, E., \& Arnetti, S. (2014). Pelaksanaan Pungutan Pajak Bahan Galian Golongan C dalam Menunjang Pendapatan Asli Daerah Kabupaten Solok Selatan. Jurnal Ilmu Hukum Riau, 4(1), 9085, p. 13-14.

8 Yuliani, M. (2013). Dampak Penambangan Batu Gunung Di Desa Merangin Kecamatan Kuok Ditinjau Menurut Ekonomi Islam (Doctoral Dissertation, Universitas Islam Negeri Sultan Syarif Kasim Riau), p. 93-94.

9 Aminah, A. (2015). Tambang Rakyat, Berkah Atau Musibah? (Studi Tentang Tambang Emas Rakyat Di Gunong Ujeun Kabupaten Aceh Jaya). Jurnal Public Policy, 3(1), p. 40.
} 
lingkungan dan penggalian perlu diperhatikan. Dengan adanya berbagai perubahan yang terjadi pada bentang alam, dilihat dari habitat flora dan fauna yang banyak adanya perubahan, selain itu tingkat kesuburan alam pun ikut berubah dikarenakan pelaku usaha yang mengabaikan pelestarian lingkungan. ${ }^{10}$ Sehingga praktek galian $\mathrm{C}$ di Kabupaten Karangasem didominasi oleh pelaku usaha yang belum menerapkan baku mutu lingkungan dimana terdapat pelarangan aktivitas pertambangan galian $\mathrm{C}$ terhadap pelaku usaha terkait daerah dengan ketinggian lebih dari 500 (lima ratus) meter diatas permukaan laut dalam melakukan aktivitas pertambangan seperti yang sudah diperingatkan oleh Pemerintah daerah dan masyarakat diminta untuk mentaatinya yang tercantum dalam Perda RTRW Nomor 17 Tahun 2012). ${ }^{11}$

Adanya regulasi yang telah dimiliki dan sebagai payung hukum untuk perlindungan maupun pengelolaan lingkungan di Kabupaten Karangasem terhadap galian $C$ dapat diukur melalui baku mutu lingkungan sebagai ukuran batas unsur pencemaran lingkungan, sehingga dalam penyelenggaraan pemerintah pusat dan daerah serta pengaturannya terletak dalam peningkatan pelestarian lingkungan yang digunakan untuk pencegahannya diatur dalam baku mutu lingkungan terhadap penambangan galian C agar masyarakat mentaati aturan yang sudah berlaku tersebut. ${ }^{12}$ Agar pemanfaatan dari berbagai kekayaan alam tersebut tidak menjadi pengurasan maka dikeluarkan suatu kebijakan hukum yang dilandasi dengan adanya sebuah perlindungannya maupun sistem pengelolaan lingkungan hidup di Kabupaten Karangasem. Kedepannya masyarakat agar memperhatikan serta peduli dengan lingkungan sekitarnya. ${ }^{13}$ Sehingga dari permasalahan yang terjadi di Kabupaten Karangasem terkait kasus galian $C$ penulis tertarik untuk mengkaji terkait bagaimanakah aturan yuridis baku mutu lingkungan terkait galian $\mathrm{C}$ di Kabupaten Karangasem dan yang kedua bagaimanakah tindakan mencegah pencemaran lingkungan dari aktivitas pertambangan galian $\mathrm{C}$.

\section{Metode Penelitian}

Dalam penelitian dilakukan dengan metode penelitian hukum normatif. ${ }^{14}$ Dalam hal ini pendekatan statue approach, suatu pendekatan secara peraturan perundangundangan diantaranya: pertama, comprehensive law dimana bisa dilihat dari antara hukum yang satu memiliki keterkaitan dengan yang lain, kedua all-inclusive, merupakan norma yang ada dapat menampung permasalahan hukum yang sedang terjadi menjadi satu kesatuan, dan yang terakhir systematic, yaitu norma yang satu dan

${ }^{10}$ Cahyanti, N. L. (2015). Analisis Izin Usaha Galian Golongan C Terhadap Penerimaan Pajak Daerah Di Kabupaten Karangasem. Jurnal Akuntansi Profesi, 4(1), p. 38-39.

11 Wiratmini, N. P. E. (2018). Izin Pertambangan di Karangasem Terbentur Perda RTRW, Bisnis.com. URL: https://bali.bisnis.com/read/20180409/538/782068/izin-pertambangandi-karangasem-terbentur-perda-rtrw, diakses 6 Januari 2020.

12 Firmansyah, A. A., \& Evendia, M. op. cit, p. 25-29.

${ }^{13}$ Rahmadi, T. (2019). Hukum Lingkungan di Indonesia. Jakarta: Raja Grafindo, p. 2.

14 Priyanta, M. (2019). Regulasi Perizinan Mendirikan Bangunan dalam Mendukung Kemudahan Berusaha Menuju Bangsa yang Adil dan Makmur. Jurnal Magister Hukum Udayana (Udayana Master Law Journal), 8(3), 371-385, DOI: https://doi.org/10.24843/JMHU.2019.v08.i03.p06, p. 26 
yang lainnya saling berkaitan sehingga tersusun secara hirarki. ${ }^{15}$ Bahan hukum yang dikaji dan dianalisis terdiri dari sumber bahan hukum primer berupa kajian dari sebuah peraturan perundang-undangan yang masih berlaku serta dikaitkan dengan permasalahan hukum yang sedang terjadi dalam penulisan ini ${ }^{16}$ kemudian sumber bahan hukum sekunder berupa buku-buku ilmu hukum, hasil penelitian hukum dan sumber bahan hukum tersier berupa kamus hukum, internet. ${ }^{17}$ Selanjutnya dalam penulisan ini menggunakan teknik studi dokumen sebagai teknik pengumpulan bahan hukumnya dan menggunakan teknik analisis yaitu teknik argumentatif dan teknik analisis deskriptif. ${ }^{18}$

\section{Hasil dan Pembahasan}

\subsection{Aturan Yuridis Baku Mutu Lingkungan Terkait Galian C di Kabupaten Karangasem}

Penetapan terkait ambang batas pengelolaan lingkungan adanya larangan dalam setiap aktivitas pertambangan yang dilihat dari ketinggian yang ukurannya lebih dari 500 (lima ratus) meter diatas permukaan laut dalam penggalian bahan mineral bukan logam dan batuan. Sehingga masyarakat perlu meningkatkan perhatiannya mencegah berbagai pencemaran serta mampu meningkatkan pelestarikan fungsi lingkungan hidup. ${ }^{19}$ Jika hal tersebut tidak ditaati niscaya kerusakan lingkungan akan terjadi. Begitu pula sudah adanya himbauan baik aturan yuridis hukumnya di dalam undangundang Lingkungan hidup akan batasan-batasan dalam aktivitas pertambangan yang telah dilakukan dan selalu mengajak masyarakat untuk dapat mengatur berbagai kegiatan perindustrian dan kegiatan pembangunan perekonomian yang dilakukannya untuk memperoleh keuntungan secara finansial pada umumnya jangan sampai mengorbankan pelestarian fungsi lingkungan hidup dan menyebabkan pencemaran lingkungan yang dapat merugikan manusia dan lingkungan yang ada. ${ }^{20}$ Peningkatan kerusakan lingkungan yang terjadi akibat galian C di Kabupaten Karangasem, Desa Sebudi adalah adanya kubangan bekas galian $C$ nyaris menyerupai danau setelah dipenuhi air hujan yang mengalir dari lereng Gunung Agung. Lubang-lubang bekas galian $C$ tersebut dulunya cukup dalam sekitar 70 meter, namun setelah beberapa kali diterjang banjir air hujan yang mengalir dari Gunung Agung kini kedalamannya hanya tersisa 20 meter saja. Kondisi ini sempat dikhawatirkan oleh masyarakat apabila cubang-cubang tersebut jebol maka material lumpur bercampur air dan pasir tersebut akan mengalir ke sungai Tukad Langon kebawah dimana di sekitaran sungai terdapat pemukiman. Adanya pengrusakan lingkungan tersebut disebabkan karena kurangnya pengendalian baku mutu lingkungan dalam melakukan aktivitas pertambangan dan

${ }^{15}$ Firmansyah, A. A., \& Evendia, M. op.cit, p. 22

16 Hardjanto, U. S., Gutami, B., \& Nugroho, E. O. (2016). Pengaturan Pertambangan Galian C di Jawa Tengah dengan Lahirnya Undang-undang Nomor 23 Tahun 2014 Tentang Pemerintahan Daerah. Diponegoro Law Review, 5(3), 19293, p. 2.

17 Tanjung, N. P. P., \& Wibisana, M. W. Politik Hukum Penanganan Sampah Plastik Sekali Pakai, DOI: https://doi.org/10.24843/JMHU.2020.v09.i01.p15, p.213

18 Putri, P. D. P., \& Sarjana, I. M. Pengaturan Lembaga Gadai Online dalam Dimensi 4.0 di Indonesia, DOI: https://doi.org/10.24843/JMHU.2020.v09.i01.p12, p. 174.

19 Wiratmini, N. P. E. loc. cit.

${ }^{20}$ Kristianto, F. (2018).Karangasem Bakal Kejar Pajak Galian C Melalui Perbup Terbaru, Bisnis.com. URL: https://bali.bisnis.com/read/20180528/537/800543/karangasem-bakalkejar-pajak-galian-c-melalui-perbup-terbaru, diakses 6 Januari 2020 
kurangnya pengawasan pengelolaan lingkungan hidup oleh pemerintah daerah. Dalam meminimalisir hal tersebut sebaiknya pemerintah melakukan pengendalian secara maksimal karena bila dilihat secara langsung beberapa usaha galian $C$ di Desa Sebudi belum mentaati aturan yang tercantum di dalam Perda RTRW Kabupaten Karangasem terkait pelarangan aktivitas pertambangan. ${ }^{21}$ Untuk tetap menjaga pelestarian lingkungan hidup diharapkan masyarakat dapat bersinergi untuk mentaati aturan yuridis baku mutu lingkungan yaitu sebagai tindakan maupun daerah ikut mengeluarkan peraturan hukum lingkungan untuk daerahnya masing-masing dan ditaati oleh masyarakat yang ada di daerah tersebut. ${ }^{22}$ Bila hal tersebut diterapkan oleh seluruh lapisan masyarakat niscya pencemaran itu tidak akan terjadi bila sadar akan pentingnya menjaga lingkungan hidup dengan standar yang sudah ada bahkan tanpa melakukan pelanggaran yang ada. Masyarakat harus sadar dengan mengikuti aturan yang ada terkait baku mutu lingkungan yang sudah diundangkan dan wajib mentaatinya.

\subsection{Tindakan Mencegah Pencemaran Lingkungan dari Aktivitas Pertambangan Galian C}

Kerusakan yang ditimbulkan oleh aktivitas Galian C yang terdapat di Kabupaten Karangasem dapat dilakukan dengan upaya pengendalian maupun pengelolaan lingkungan hidup yang erat kaitannya dengan kesadaran masyarakat yang melakukan aktivitas galian $\mathrm{C}$ dalam kegiatan sehari-hari yang digunakan untuk menunjang perekonomiannya. Oleh sebab itu dilakukan suatu pengendalian serta mampu mengelola lingkungan untuk mewujudkan kesejahteraan masyarakat. Negara menjadikan kesejahteraan (welfare state) dengan memperhatikan tingkat kesejahteraan yang dilihat dari segala aktivitas penyelenggaraan negara diorientasikan. ${ }^{23}$ Melestarikan dan melindungi keberlangsungan lingkungan hidup pemerintah telah mengeluarkan berbagai macam kebijakan yang ada di pusat maupun di daerah sehingga masyarakat dan pemerintah harus saling bersinergi. Peranan pemerintah daerah untuk melestarikan lingkungan dilihat dari dikeluarkannya Undang-Undang Nomor 9 Tahun 2015 tentang Perubahan Kedua Atas Undang-Undang Nomor 23 Tahun 2014 tentang Pemerintah Daerah. Begitu juga sebaliknya pemerintah pusat mengeluarkan UU Nomor 32 Tahun 2009 tentang Lingkungan Hidup yang bertujuan untuk mengajak masyarakat peduli akan baik buruknya atau berbagai dampak yang akan terjadi bila mengabaikan kondisi lingkungan tanpa diimbangi dengan pemulihan. Dengan dikeluarkan kewenangan tersebut pemerintah daerah memiliki tanggung jawab untuk keikutsertaannya dalam melindungi kerusakan lingkungan. Tanggung jawab tersebut bertujuan untuk mengurangi resiko kerusakan lingkungan hidup. Apabila pemerintah pusat dan pemerintah daerah saling bersinergi maka akan mengurangi kerusakan lingkungan hidup yang terjadi, terutama kaitannya dengan

21 https://www.balipuspanews.com/kubangan-bekas-galian-c-desa-sebudi-karangasem menyerupai-danau.html, diakses 28 Oktober 2019

22 Firmansyah, A. A., \& Evendia, M. op. cit, p. 55

${ }^{23}$ Hakim, D. A. (2015). Politik hukum lingkungan hidup di Indonesia berdasarkan UndangUndang Nomor 32 Tahun 2009 tentang Perlindungan dan Pengelolaan Lingkungan Hidup. Fiat Justisia: Jurnal Ilmu Hukum, 9(2), p. 115 
pengelolaan pertambangan di daerah yang bertujuan untuk melindungi kerusakan lingkungan galian C di Kabupaten Karangasem. ${ }^{24}$

Hal ini terlihat pada kebijakan baru yaitu wewenang dalam kekayaan berbagai sumber daya mineral maupun pertambangan menjadi kewenangan pemerintah daerah tercantum dalam Undang-Undang Nomor 9 Tahun 2015 tentang Perubahan Kedua Atas Undang-Undang Nomor 23 Tahun 2014 tentang Pemerintah Daerah. Adapun kewenangan tersebut yaitu untuk menetapkan dan menerbitkan pertambangan mineral bukan logam dan batuan dalam 1 (satu) daerah provinsi dan wilayah laut sampai dengan jarak 12 (dua belas) mil. Berbagai cara untuk menanggulangi terjadinya suatu pencemaran atau kerusakan lingkungan hidup. Maka dari itu perlu dilaksanakan pelestarian fungsi lingkungan hidup meliputi: pertama, adanya tindakan pencegahan; kedua, adanya tindakan penanggulangan; ketiga waktunya untuk pemulihan. Ada baiknya itu dilakukan oleh pemerintah, pelaku usaha dan masyarakat sekitar. Adanya ukuran batas yang telah ditentukan terkait adanya perubahan sifat fisik, kimia atau hayati lingkungan hidup agar semua komponen tetap melestarikannya yang dinyatakan dalam baku mutu lingkungan hidup. ${ }^{25}$ Dengan adanya batasan tersebut diharapkan masyarakat sebagai pelaku usaha di Kabupaten Karangasem dapat mentaati aturan yang telah diberlakukan. Kemudian dengan diterbitkannya Perda Bali Nomor 4 Tahun 2017 Tentang Pengelolaan Pertambangan Mineral Bukan Logam dan Batuan dalam Pasal 2 bahwa kewenangan yang dimiliki oleh seorang gubernur untuk meningkatkan penertiban Wilayah Ijin Usaha Pertambangan (WIUP) batuan dalam wilayah provinsi dan wilayah laut sampai 12 (dua belas) mil.26

Diundangkannya Perda Nomor 17 Tahun 2012 tentang RTRW Kabupaten Karangasem Tahun 2012-2032 agar seluruh komponen masyarakat sebagai pelaku pertambangan galian $\mathrm{C}$ di Kabupaten Karangasem untuk mentaati aturan yang sudah ditetapkan. Dalam rangka pengendalian dampak lingkungan yang terjadi di Kabupaten Karangasem diterapkannya upaya preventif yang dilaksanakan secara maksimal sebagai instrumen maupun syarat-syarat yang terdapat di dalam baku mutu lingkungan. Selain itu adanya upaya yang ditempuh jika terjadi pelanggaran melalui upaya diluar pengadilan yang disebut dengan non litigasi dan melalui pengadilanya disebut dengan litigasi. ${ }^{27}$ Upaya-upaya yang ditempuh jika terjadi pelanggaran yaitu adalah dengan cara menerapkan hukum yang bersifat represif yaitu penegakan hukum lingkungan ada tiga jalan jenis atau tiga jalan dalam menegakkan hukum lingkungan yaitu dengan cara menerapkan hukum yang bersifat represif. Walaupun adanya sanksi yang mengatur pencemaran lingkungan seperti dibidang pertambangan, namun masih

24 Putri, A. D. (2018). Kerusakan Lingkungan Akibat Kewenangan Pemerintah Daerah Dalam Pemberian Izin Lingkungan (Doctoral Dissertation, Universitas Muhammadiyah Surakarta), p. 2-4

${ }^{25}$ Fadhilah, N. L. (2016). Implikasi Pemberlakuan Undang-Undang No. 9 Tahun 2015 Tentang Perubahan Kedua Undang-Undang No. 23 Tahun 2014 Tentang Pemerintah Daerah Atas Perizinan Pertambangan Terhadap Legislasi Di Daerah. Jurnal Ilmiah Pendidikan Pancasila Dan Kewarganegaraan, 1(2), p. 95-98.

26 https://news.beritabali.com/read/2017/11/17/201711170007/gubernur-surati-bupatikarangasem-soal-galian-c-ada-apa (diakses tanggal 28 Oktober 2019).

27 Wijoyo, Suparto. (2003). Penyelesaian sengketa Lingkungan (Environmental Disputes Resolution), Surabaya: Airlangga, p. 9-11. 
saja terdapat masyarakat yang melanggar aturan tersebut. Sehingga perlunya peran penting pemerintah saat ini dilihat dari pemerintah pusat dan pemerintah daerah harus saling bekerjasama untuk bertindak tegas dalam penanganan kasus galian $\mathrm{C}$ di Kabupaten Karangasem. ${ }^{28}$ Apabila itu dibiarkan begitu saja dan dilakukan secara berkelanjutan tanpa memperhatikan baku mutu lingkungan yang sudah tertera bahwa pelarangan aktivitas pertambangan maka akan menimbulkan berbagai bencana karena penggalian yang seharusnya sudah ada batas dengan ketinggian di atas permukaan laut apabila hal tersebut diabaikan maka akan menimbulkan bencana alam yaitu banjir, hal tersebut diakibatkan karena adanya kubangan-kubangan dari penggalian yang dilakukan secara terus-menerus. Dalam melestarikan lingkungan pertambangan selain dengan mengikuti batasan yang telah diberikan maka adanya pemulihan yang seharusnya dilakukan oleh pelaku usaha galian C di Kabupaten Karangasem. ${ }^{29}$

\section{Kesimpulan}

Baku mutu lingkungan hidup telah diatur dalam Pasal 1 angka 13 Undang-Undang Nomor 32 Tahun 2009 tentang Perlindungan dan Pengelolaan Lingkungan Hidup agar kegiatan perindustrian dan kegiatan pembangunan perekonomian jangan sampai mengorbankan pelestarian fungsi lingkungan hidup. Peranan pemerintah daerah untuk melestarikan lingkungan dilihat dari dikeluarkannya Undang-Undang Nomor 9 Tahun 2015 tentang Perubahan Kedua Atas Undang-Undang Nomor 23 Tahun 2014 tentang Pemerintah Daerah. Adapun kewenangan tersebut yaitu untuk menetapkan dan menerbitkan pertambangan mineral bukan logam dan batuan dalam 1 (satu) daerah provinsi dan wilayah laut sampai dengan jarak 12 (dua belas) mil. Peraturan Daerah Provinsi Bali Nomor 4 Tahun 2017 Tentang Pengelolaan Pertambangan Mineral Bukan Logam dan Batuan adanya kewenangan Gubernur untuk menertibkan Ijin Usaha Pertambangan (IUP) dan melakukan monitoring, pembinaan, dan pengawasan kegiatan pertambangan batuan. Selanjutnya penegakan hukum Kabupaten Karangasem memiliki Peraturan Daerah Nomor 17 Tahun 2012 tentang Rencana Tata Ruang Wilayah Kabupaten Karangasem Tahun 2012-2032 adanya pelarangan aktivitas pertambangan tercantum Pasal 71 bahwa dilarang melakukan kegiatan penggalian bahan mineral bukan logam dan batuan pada kawasan yang mencapai ketinggian lebih dari 500 meter di atas permukaan laut. Hal tersebut wajib ditaati oleh pelaku usaha dan masyarakat di lingkungan galian $\mathrm{C}$ dan dilaksanakannya pelestarian fungsi lingkungan hidup meliputi: pertama, pencegahan; kedua, penanggulangan; dan ketiga pemulihan demi mempertahankan pelestarian lingkungan di Kabupaten Karangasem.

\section{Daftar Pustaka}

\section{$\underline{\text { Buku }}$}

Marzuki Mahmud Peter. (2005). Penelitian Hukum. Jakarta: Kencana Prenada

Maryunani.(2018). Pengelolaan Sumber Daya Alam dan Pembangunan Ekonomi Secara Berkelanjutan. Malang: UB Press

Siahaan, N. H. T. (2009). Hukum Lingkungan, cet. Ke-2, Jakarta: Pancuran Alam.

${ }^{28}$ Mantra, Tria; Dirksen, A A Ngr Gd. Penegakan Hukum Lingkungan Terkait Galian C Di Desa Sebudi Kabupaten Karangasem. Kertha Negara: Jurnal Ilmu Hukum, Vol. 01, No. 06, September 2013, p. 3-5.

29 https:// bali.bisnis.com/read/20180409/538/782068/izin-pertambangan-di-karangasemterbentur-perda-rtrw, diakses 6 Januari 2020 
Rahmadi, T. (2019). Hukum Lingkungan di Indonesia. Jakarta: Raja Grafindo

\section{Jurnal}

Aminah, A. (2015). Tambang Rakyat, Berkah Atau Musibah?(Studi Tentang Tambang Emas Rakyat Di Gunong Ujeun Kabupaten Aceh Jaya). Jurnal Public Policy, 3(1). https://doi.org/10.35308/jpp.v3i1.715

Astrawan, I. W. G., Nuridja, I. M., Dunia, I. K., \& Erg, M. (2014). Analisis SosialEkonomi Penambang Galian C Di Desa Sebudi Kecamatan Selat Kabupaten Karangasem Tahun 2013. Jurnal Pendidikan Ekonomi Undiksha, 4(1). http://dx.doi.org/10.23887/jjpe.v4i1.1906

Cahyanti, N. L. (2015). Analisis Izin Usaha Galian Golongan C Terhadap Penerimaan Pajak Daerah Di Kabupaten Karangasem. Jurnal Akuntansi Profesi, 4(1), 35-44. http://dx.doi.org/10.23887/jap.v4i1.21071

Fadhilah, N. L. (2016). Implikasi Pemberlakuan Undang-Undang No. 9 Tahun 2015 Tentang Perubahan Kedua Undang-Undang No. 23 Tahun 2014 Tentang Pemerintah Daerah Atas Perizinan Pertambangan Terhadap Legislasi Di Daerah. Jurnal Ilmiah Pendidikan Pancasila Dan Kewarganegaraan, 1(2), 91-101. http://dx.doi.org/10.17977/jippk.v1i2.9638

Firmansyah, A. A., \& Evendia, M. (2014). Politik Hukum Penetapan Baku Mutu Lingkungan sebagai Instrumen Pencegahan Pencemaran Lingkungan Hidup. Kanun: Jurnal Ilmu Hukum, 16(1), 19-37. Vol. 16, No. 01 April, 2014

Hakim, D. A. (2015). Politik hukum lingkungan hidup di Indonesia berdasarkan Undang-Undang Nomor 32 Tahun 2009 tentang Perlindungan dan Pengelolaan Lingkungan Hidup. Fiat Justisia: Jurnal Ilmu Hukum, 9(2). https://doi.org/10.25041/fiatjustisia.v9no2.592

Hardjanto, U. S., Gutami, B., \& Nugroho, E. O. (2016). Pengaturan Pertambangan Galian C di Jawa Tengah dengan Lahirnya Undang-undang Nomor 23 Tahun 2014 Tentang Pemerintahan Daerah. Diponegoro Law Review, 5(3), 19293,

Jumali, J., Farhan, N., Razma, O., Amalia, N. F., \& Sudarmiati, S. (2017). Peran Pemerintah Daerah Dalam Mengoptimalisasi Penanganan Pencemaran Lingkungan di Wilayah Pesisir Kota Batam. Jurnal Selat, 5(1), 25-35. Vol. 05 No. 01, Oktober 2017

Mantra, Tria; Dirksen, A A Ngr Gd. Penegakan Hukum Lingkungan Terkait Galian C Di Desa Sebudi Kabupaten Karangasem. Kertha Negara: Jurnal Ilmu Hukum. Vol. 01, No. 06, September 2013

Pertiwi, I. D. A. E., \& Ludigdo, U. (2013). Implementasi Corporate Social Responsibility Berlandaskan Budaya Tri Hita Karana. Jurnal Akuntansi Multiparadigma. http://dx.doi.org/10.18202/jamal.2013.12.7208

Priyanta, M. (2019). Regulasi Perizinan Mendirikan Bangunan dalam Mendukung Kemudahan Berusaha Menuju Bangsa yang Adil dan Makmur. Jurnal Magister Hukum Udayana (Udayana Master Law Journal), 8(3). https:// doi.org/10.24843/JMHU.2019.v08.i03.p06

Putri, P. D. P., \& Sarjana, I. M. Pengaturan Lembaga Gadai Online dalam Dimensi 4.0 di Indonesia. https:// doi.org/10.24843/JMHU.2020.v09.i01.p12

Rissamasu, F., Darma, R., \& Tuwo, A. (2011). Pengelolaan Penambangan bahan Galian Golongan C di Kabupaten Merauke. Ejournal Pascasarjana Universitas Hasanuddin. https://doi.org/10.29239/j.agrikan.11.2.44-50

Tanjung, N. P. P., \& Wibisana, M. W. Politik Hukum Penanganan Sampah Plastik Sekali Pakai. https:// doi.org/10.24843/JMHU.2020.v09.i01.p15 
Umar, N. A., \& Budi, S. (2011). Penegakan Hukum Lingkungan di Indonesia. Jurnal Wacana Hukum, 10(2). https://doi.org/10.33061/1.jwh.2011.10.2.253

Valia, E., \& Arnetti, S. (2014). Pelaksanaan Pungutan Pajak Bahan Galian Golongan C dalam Menunjang Pendapatan Asli Daerah Kabupaten Solok Selatan. Jurnal Ilmu Hukum Riau, 4(1), 9085. Vol. 04, No. 01, 2014.

\section{Tesis atau Disertasi}

Putri, A. D. (2018). Kerusakan Lingkungan Akibat Kewenangan Pemerintah Daerah Dalam Pemberian Izin Lingkungan (Doctoral Dissertation, Universitas Muhammadiyah Surakarta).

Yuliani, M. (2013). Dampak Penambangan Batu Gunung Di Desa Merangin Kecamatan Kuok Ditinjau Menurut Ekonomi Islam (Doctoral Dissertation, Universitas Islam Negeri Sultan Syarif Kasim Riau)

\section{Internet}

Wiratmini, N. P. E. (2018). Izin Pertambangan di Karangasem Terbentur Perda RTRW, Bisnis.com.

URL: https://bali.bisnis.com/read/20180528/537/800543/karangasem-bakal-kejarpajak-galian-c-melalui-perbup-terbaru, (diakses 6 Januari 2020).

Kristianto, F. (2018). Karangasem Bakal Kejar Pajak Galian C Melalui Perbup Terbaru, Bisnis.com. https:/ / bali.bisnis.com/read/20180528/537/800543/karangasem-bakal-kejarpajak-galian-c-melalui-perbup-terbaru, (diakses 6 Januari 2020).

https://news.beritabali.com/read/2017/11/17/201711170007/gubernur-suratibupati-karangasem-soal-galian-c-ada-apa (diakses tanggal 28 Oktober 2019)

https://www.balipuspanews.com/kubangan-bekas-galian-c-desa-sebudi karangasemmenyerupai-danau.html, (diakses 28 Oktober 2019)

https://www.balipost.com/news/2018/05/13/45336/Marak,Penambangan-Pasir-diEks...html, (diakses 26 Juni 2020)

\section{Peraturan Perundang-Undangan}

Undang-Undang Nomor 9 Tahun 2015 tentang Perubahan Kedua Atas UndangUndang Nomor 23 Tahun 2014 tentang Pemerintah Daerah (Lembaran Negara Republik Indonesia Tahun 2015 Nomor 58, Tambahan Lembaran Negara Republik Indonesia Nomor 5657)

Undang-Undang Nomor 32 Tahun 2009 tentang Perlindungan dan Pengelolaan Lingkungan Hidup (Lembaran Negara Republik Indonesia Tahun 2009 Nomor 140, Tambahan Lembaran Negara Republik Indonesia Nomor 5059)

Peraturan Pemerintah Nomor 27 tahun 1980 tentang Penggolongan Bahan-bahan Galian (Lembaran Negara Republik Indonesia Tahun 1980 Nomor 22, Tambahan Lembaran Negara Republik Indonesia Nomor 3174)

Peraturan Daerah Provinsi Bali Nomor 4 Tahun 2017 Tentang Pengelolaan Pertambangan Mineral Bukan Logam dan Batuan (Lembaran Daerah Provinsi Bali Tahun 2017, Tambahan Lembaran Daerah Provinsi Bali Nomor 4)

Peraturan Daerah Nomor 17 Tahun 2012 tentang Rencana Tata Ruang Wilayah Kabupaten Karangasem Tahun 2012-2032 (Lembaran Daerah Kabupaten Karangasem Tahun 2012, Tambahan Lembaran Daerah Kabupaten Karangasem Nomor 17) 